\title{
Dynamika funkcji kontrolno-zarządczych miast Europy Środkowo-Wschodniej w czasie spowolnienia gospodarczego
}

Piotr Raźniak*

Sławomir Dorocki**

Anna Winiarczyk-Raźniak ${ }^{* * *}$

\section{Wstęp}

Miasta w Europie Środkowo-Wschodniej w okresie przejścia z gospodarki centralnie sterowanej do rynkowej - przełom lat 80. i 90. XX w. - badane są przede wszystkim w odniesieniu do transformacji ustrojowej. Jednak rozwój tych miast, który zaczął się w latach 90 . XX w., uwarunkowany jest głównie procesami metropolizacji (Smętkowski 2015). Zmiana systemu politycznego, przejście z gospodarki centralnie sterowanej do rynkowej i demokratyzacja życia publicznego są szczególnie ważne w przypadku krajów postsocjalistycznych (Tsenkova 2008). Na początku lat 90. XX w., wraz z upadkiem Związku Radzieckiego, doszło do załamania się gospodarek w całej Europie Środkowo-Wschodniej (Connoly 2012). W tym okresie przeprowadzono masową prywatyzację przedsiębiorstw państwowych, których udziałowcami stały się korporacje zagraniczne, głównie spoza Europy Środkowo-Wschodniej (Froot 1994). Proces ten był szczególnie widoczny w sektorach finansowym i handlowym oraz na rynku nieruchomości komercyjnych; dotyczył także kapitału portfelowego. Międzynarodowe korporacje obecne są również w branży nowych technologii, zwłaszcza w sektorach kapitałochłonnych, np. w przemyśle biotechnologicznym i farmaceutycznym charakteryzującym się dużym ryzkiem finansowym i długim terminem zwrotu (Dorocki, Boguś 2014; Wójtowicz, Dorocki 2014). Głównymi inwestorami

\footnotetext{
* Piotr Raźniak - doktor nauk o Ziemi, Uniwersytet Pedagogiczny w Krakowie, Instytut Geografii, e-mail:prazniak@up.krakow.pl.

** Sławomir Dorocki - doktor nauk o Ziemi, Uniwersytet Pedagogiczny w Krakowie, Instytut Geografii, e-mail: sdorocki@up.krakow.pl.

*** Anna Winiarczyk-Raźniak - doktor nauk o Ziemi, Uniwersytet Pedagogiczny w Krakowie, Instytut Geografii, e-mail: arazniak@up.krakow.pl.
} 
w sektorze biotechnologii i farmacji w Europie Środkowej i Wschodniej były korporacje z Wielkiej Brytanii, Niemiec i Indii (IMAP. Global Pharma \& Biotech Report 2014). Inwestycje w sektorze nowych technologii charakteryzują się głównie delokalizacją produkcji, a ośrodki badawcze zlokalizowane są głównie w Europie Zachodniej. Przykładem mogą być działania podejmowane przez międzynarodową firmę Reckitt Benckiser. Firma ta przejmuje zagraniczne firmy głównie po to, aby łatwiej było jej wprowadzić swoje towary na lokalny rynek, ponieważ w przypadku rynku medycznego i leków zagranicznych wiąże się to z długotrwałymi i kosztownymi procesami (Dorocki 2014). Również w przypadku inwestycji w innych sektorach głównym celem było wejście korporacji na zagraniczne rynki.

Pozytywną stroną przemian gospodarczych np. w Polsce jest zdecydowany wzrost inwestycji FDI polskich firm w krajach Unii Europejskiej, zaznaczający się po wstąpieniu kraju do struktur UE w 2004 r. (Wojciechowski, Lubacha-Sember 2014). Sytuacja finansowa największych korporacji tego regionu poprawia się, dzięki czemu coraz częściej trafiają one do grona największych korporacji światowych (Raźniak, Nowotnik 2015; Raźniak, Winiarczyk-Raźniak 2014).

Wielkie korporacje mają duży wpływ na rangę miasta na arenie międzynarodowej. Już P. Hall (1966), który określił teoretyczne podstawy koncepcji world city, zwracał uwagę na funkcje kontrolno-zarządcze miast w gospodarce, przejawiające się m.in. lokalizowaniem w nich siedzib dużych korporacji prowadzących międzynarodową wymianę handlową. Koncepcja ta była rozwijana przez J. Friedmanna (1986), który przedstawił siedem hipotez osadzonych w procesach globalizacji, stwierdzając, że funkcje kontrolno-zarządcze są powiązane z sektorem produkcyjnym oraz ze strukturą zatrudnienia. Z kolei S. Sassen (1991) stwierdziła, że zmiany w funkcjonowaniu miast miały ogromny wpływ zarówno na międzynarodową działalność gospodarczą, jak i formę miejską. Miasta kontrolują ogromne zasoby gospodarcze, a zgromadzony w ośrodkach miejskich kapitał wykazuje się dużą mobilnością, co wydaje się najważniejszą cechą globalizacji (Dorocki 2012). Znacznie zmniejszają się odległości, jeśli chodzi o przemieszczanie się siły roboczej i środków finansowych. Powstaje zatem międzynarodowy system gospodarczy, w którym zarówno komunikacja pomiędzy ośrodkami, jak i ich władza są większe (Sassen 2000).

Od lat 70. XX w. w Stanach Zjednoczonych zaobserwowano, że wielkie korporacje zaczęły przenosić swoje siedziby z dużych miast do mniejszych ze względu na niższe koszty utrzymania i lepszą infrastrukturę (Lyon, Salmon 1995). Obecnie w światowej gospodarce ma miejsce globalizacja korporacyjna, przejawiająca się tworzeniem koalicji pomiędzy firmami w celu sprostania ciągle rosnącym wymogom rynku globalnego, w tym ograniczania kosztów. Prowadzi to do rozbudowywania globalnych powiązań biznesowych między największymi korporacjami światowymi (Dorocki 2010; Rosińska-Bukowska 2015). Jednocześnie należy pamiętać, że powiązania pomiędzy poszczególnymi firmami są słabsze niż te pomiędzy miastami (Liu, Derudder, Witlox, Hoyler 2014). 
S. Sassen (2006) zauważa, że coraz więcej miast ma drugorzędne znaczenie pod względem obecności wysoko wyspecjalizowanych funkcji. Jednocześnie zaawansowane usługi producenckie nadal zlokalizowane są w dużych miastach, a funkcje kontrolno-zarządcze przenoszone są do ośrodków subregionalnych i regionalnych. Badania nad funkcjami i wynikami finansowymi korporacji silnie zaznaczają się w literaturze, zwłaszcza odnośnie do miast jako ośrodków kontrolno-zarządczych światowej gospodarki (Godfrey, Zhou 1999; Alderson, Beckfield 2004; Taylor, Csomós 2012; Csomós, Derudder 2013; Raźniak, Dorocki, Winiarczyk-Raźniak 2016; Raźniak, Dorocki, Winiarczyk-Raźniak 2017). Koncepcja ta staje się kluczowa dla zrozumienia znaczenia miast w procesach globalizacji. Wydaje się, że badania lokalizacji siedzib zarządów największych korporacji światowych ukazują specyficzną siłę miasta pod kątem jego funkcji kontrolnej w światowej gospodarce, jednak nie jest to oczywiście jedyny miernik pozycji ośrodka w globalnej sieci miast (Taylor 2004). Na podstawie wyników finansowych największych korporacji G. Csomós (2013) określił Command Control Index dla najważniejszych miast świata, do których pod tym względem należą: Tokio, Nowy Jork, Londyn, Pekin i Paryż.

Celem artykułu jest określenie poziomu funkcji kontrolno-zarządczych miast Europy Środkowo-Wschodniej na podstawie przychodów ze sprzedaży i zysków netto największych korporacji, których siedziby zarządu zlokalizowane są w Europie Srodkowo-Wschodniej.

\section{Źródła danych i metody}

Aby przedstawić funkcje kontrolno-zarządcze miast Europy Środkowo-Wschodniej, przeanalizowano raporty dotyczące największych korporacji Europy Środkowo-Wschodniej w latach 2008 i 2012, opracowane przez Deloitte (Deloitte Central Europe Top 500 Report). Ranking ten, publikowany od 2008 r., uwzględnia największe korporacje - jeśli chodzi o ich przychody ze sprzedaży - mające siedziby w Europie Środkowo-Wschodniej. Aby korporacja mogła znaleźć się w zestawieniu, musiała również mieć swoje przedstawicielstwa w co najmniej trzech krajach w analizowanym regionie. Lista nie uwzględnia banków i instytucji ubezpieczeniowych, których dotyczy osobne zestawienie publikowane przez Deloitte; wydaje się, że w związku ze spowolnieniem gospodarczym nie można ich pominąć w przeprowadzanej analizie. Ich negatywny wpływ na gospodarkę w przypadku kryzysu jest bardzo duży (Sassen 2011). W związku z tym do rankingu Top 500 dodano po 50 banków i instytucji ubezpieczeniowych, które również zostały opublikowane w raporcie Deliotte. W ten sposób powstała lista 600 korporacji dominujących pod względem przychodów ze sprzedaży w Europie Środkowo-Wschodniej. Deloitte opracowuje ranking dla: Albanii, Bośni i Hercegowiny, Bułgarii, Chorwacji, Czech, Estonii, Kosowa, Litwy, Łotwy, Macedonii, 
Mołdawii, Polski, Rumunii, Serbii, Słowacji, Słowenii, Ukrainy i Węgier. Poza listą znalazły się Rosja i Białoruś, ponieważ wystąpiły trudności z uzyskaniem danych z tych krajów oraz są pewne wątpliwości co do ich wiarygodności (Deloitte Central Europe Top 500 report). Analizowane w rankingu korporacje zostały zakwalifikowane przez Deloitte do dziewięciu sektorów: bankowego (banking), konsumenckiego i transportowego (consumer business and transportation), energii i surowców (energy and resources), ubezpieczeniowego (insurance), biochemicznego, medycznego i opieki zdrowotnej (life sciences and health care), produkcyjnego (manufacturing), publicznego (public sector), nieruchomości (real estate), technologii, mediów i komunikacji (technology, media and telecommunications). Lokalizację poszczególnych korporacji określano, przypisując je do obszarów metropolitalnych, w których znajduje się siedziba zarządu. Taką samą jednostką przestrzenną posługiwali się również autorzy, tworząc koncepcję world city (www.lboro.ac.uk), global city (Sassen 1991) oraz Command Control Index (Csomós 2013).

P.J. Taylor i G. Csomós (2012) stwierdzili, że funkcje kontrolno-zarządcze w światowej gospodarce tworzą korporacje z listy Forbes Global 2000. Autorzy niniejszego opracowania przyjmują, że regionalne funkcje kontrolno-zarządcze dla miast krajów Europy Środkowo-Wschodniej tworzą korporacje z listy Delolitte Central Europe Top $500+100$ największych korporacji sektora bankowego i ubezpieczeniowego.

W analizie wyników finansowych poszczególnych miast Europy Środkowo-Wschodniej wykorzystano wnioskowanie oparte na wskaźniku Command Control Index (Csomós 2013). W celu obliczenia potencjału funkcji kontrolno-zarządczej miasta wykorzystano sumę wartości przychodów ze sprzedaży oraz dochodów netto (tak jak w przypadku Command Control Index G. Csomósa) w odniesieniu do poszczególnych korporacji. W ten sposób otrzymano syntetyczny wskaźnik ekonomicznej aktywności międzynarodowych korporacji dla wybranego miasta (HQ):

$$
H Q=\sum_{i=1}^{i=n} \frac{P_{i}+D_{i}}{2}
$$

gdzie:

$P_{i}$ - udział w wartości przychodów w ogóle całej sumie wartości przychodów dla wszystkich korporacji zlokalizowanych w mieście;

$D_{i}$ - udział w wartości dochodów w całej sumie wartości dochodów dla wszystkich korporacji zlokalizowanych w mieście;

$n$ - liczba siedzib korporacji w danym mieście. 
Funkcje kontrolno-zarządcze miasta w gospodarce światowej tworzą co najmniej trzy siedziby zarządów (Csomós, Derudder 2014). W prowadzonej analizie założono również, że funkcje kontrolno-zarządcze w gospodarce Europy Środkowo-Wschodniej mają miasta, w których znajdowały się co najmniej trzy $(\mathrm{n} \geq 3)$ siedziby zarządu notowanych przez firmę Deloitte. W ten sposób otrzymano wskaźnik funkcji kontrolno-zarządczej dla miast Europy Środkowo-Wschodniej (K-Z).

W celu określenia znaczenia poszczególnych sektorów w miastach Europy Środkowo-Wschodniej obliczono ich potencjał oddziaływania międzynarodowego na podstawie udziału wartości przychodów oraz dochodów globalnych korporacji zlokalizowanych $\mathrm{w}$ danym mieście (gdzie $\mathrm{n} \geq 3$ ) dla poszczególnych sektorów. $\mathrm{W}$ ten sposób otrzymano sektorowy wskaźnik funkcji kontrolno-zarządczej dla miast Europy Środkowo-Wschodniej (sK-Z).

Należy podkreślić, że badanie dotyczy tylko 600 największych korporacji, więc zmiany analizowanych wskaźników nie muszą odzwierciedlać tendencji w całej gospodarce.

\section{Przychody ze sprzedaży i dochod̦y netto największych korporacji z siedzibą w Europie Środkowo-Wschodniej}

Analizując rysunek 1, można zauważyć, że większość 600 dominujących korporacji w regionie w 2012 r. była zlokalizowana w zachodniej części Europy Środkowo-Wschodniej, która - ogólnie rzecz biorąc - jest lepiej rozwiniętą częścią analizowanego regionu (Kincses, Nagy, Tóth 2014). Najwyższą wartością HQ cechowała się Praga $(21,27)$, na drugim miejscu znalazła się Warszawa $(16,99)$, mimo że znajduje się w niej aż 101 siedzib zarządów, a w Pradze 77. Oba miasta zdecydowanie dominują pod względem potencjału HQ nad kolejnymi ośrodkami: Budapesztem $(7,95)$, Bratysławą $(4,78)$, Kijowem $(4,62)$ i Bukaresztem $(3,08)$. Wymienione miasta są stolicami państw, jednak na kolejnych czterech pozycjach znajdują się ośrodki regionalne: Płock, Donieck, Trójmiasto i Lubin. Interesującym przypadkiem jest zajmujący 10 miejsce w rankingu Lubin, w którym znajdują się tylko dwie siedziby zarządu. Dominuje tutaj KGHM Polska Miedź SA, zajmująca się wydobyciem miedzi, która w 2012 r. zanotowała przychody ze sprzedaży w wysokości $6381 \mathrm{mln}$ Euro; zapewniło jej to 15 miejsce wśród 600 analizowanych korporacji. $Z$ drugiej strony wiele siedzib zarządów nie gwarantuje wysokich wartości wskaźnika - przykładem mogą być Lublana (15) i Wilno (13), które pod względem liczby siedzib zarządów zajmują odpowiednio 8 i 9 miejsce, ale wartość wskaźnika lokuje Lubljanę na 15 miejscu $(1,04)$, a Wilno na $18(0,90)$. 
Rysunek 1. Liczba siedzib zarządów i wartość wskaźnika HQ w miastach Europy Środkowo-Wschodniej w $2012 \mathrm{r}$.

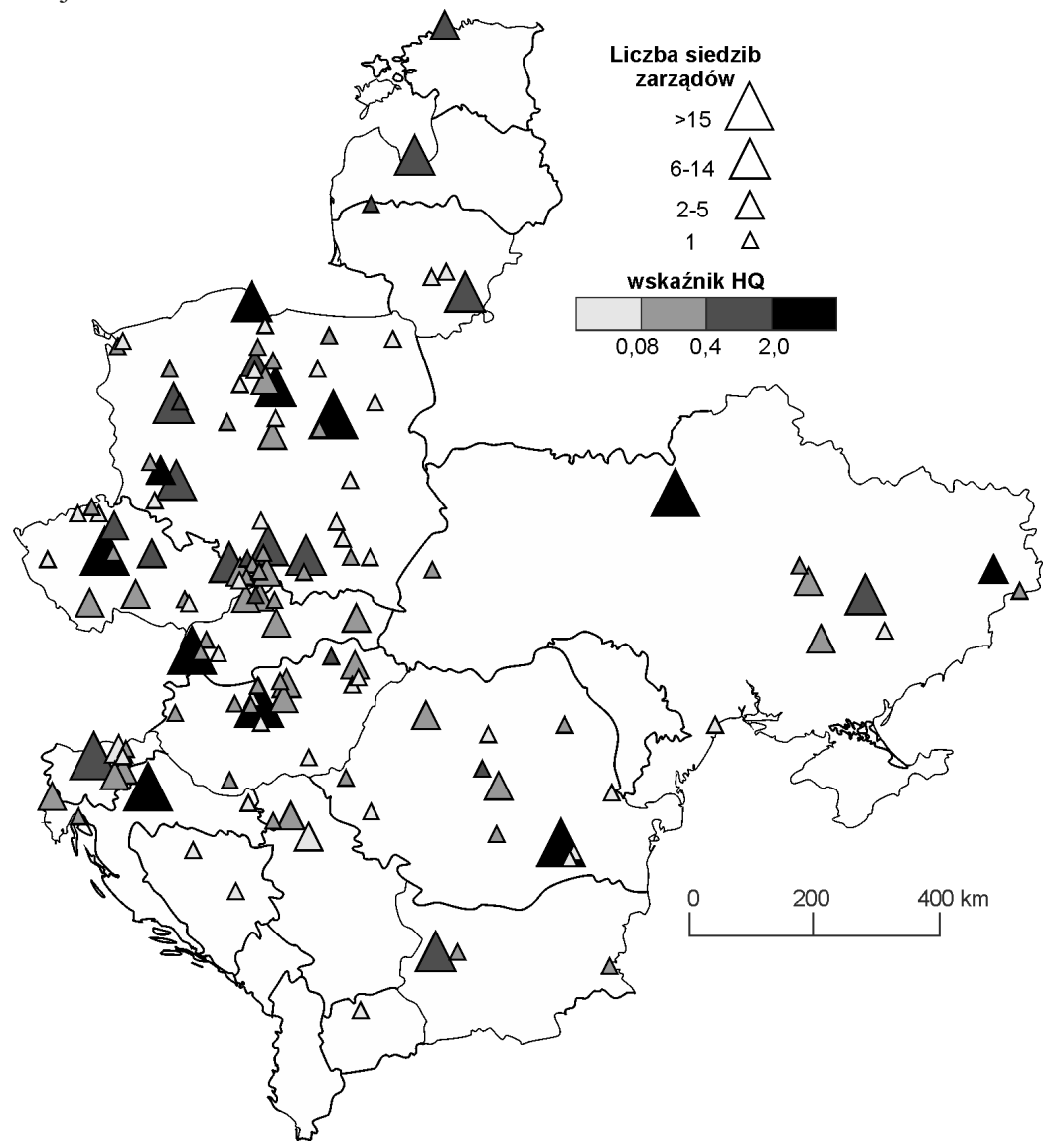

Źródło: opracowanie własne na podstawie Deloitte Central Europe Top 500 Report.

Tabela 1. Wartość wskaźnika HQ miast stołecznych i pozostałych

\begin{tabular}{|l|c|c|c|c|}
\cline { 2 - 5 } \multicolumn{1}{c|}{} & \multicolumn{2}{c|}{ HQ } & \multicolumn{2}{c|}{ Liczba siedzib zarządów } \\
\hline Wskaźnik/ranga środka & 2008 & 2012 & 2008 & 2012 \\
\hline Stolice & 68,72 & 65,09 & 379 & 381 \\
\hline Pozostałe miasta & 31,28 & 34,91 & 221 & 219 \\
\hline Razem & 100 & 100 & 600 & 600 \\
\hline
\end{tabular}

Źródło: opracowanie własne na podstawie Deloitte Central Europe Top 500 Report.

Pod względem wyników finansowych i lokalizacji siedzib zarządów dominują miasta stołeczne, jednak w latach 2008-2012 nastąpiła zmiana wartości HQ w relacji stolice - pozostałe miasta (zob. tabela 1). W 2008 r. stolice uzyskały sumaryczny wskaźnik 68,72, a pozostałe ośrodki 31,28. W 2012 r. nastąpiła niewielka 
koncentracja liczby siedzib zarządów w miastach stołecznych (z 379 w 2008 r. do $381 \mathrm{w} 2012$ r.), jednak w przypadku sumarycznego wskaźnika sytuacja była odwrotna - mimo nieco mniejszej liczby siedzib zarządów miasta regionalne i subregionalne zwiększyły swój udział o 3,6 pkt. proc., do 34,91\%, w 2012 r. Może się to wiązać $\mathrm{z}$ niższymi kosztami pracy $\mathrm{w}$ mniejszych miastach oraz $\mathrm{z}$ lepszym stanem infrastruktury, które mogą pozwolić na uzyskanie lepszych wyników finansowych. Jest to tendencja zauważana również w krajach rozwiniętych (Sassen 2006). Głównym powodem rozkwitu dużych regionów miejskich w Europie Środkowo-Wschodniej są procesy metropolizacji przejawiające się rozwojem nowoczesnych usług biznesowych i przemysłu z uwzględnieniem występującego tam potencjału badawczo-rozwojowego (Smętkowski 2014; Zuzańska-Żyśko 2016).

W Europie Centralnej 600 badanych korporacji w 2008 r. było zlokalizowanych w 144 miastach, a w 2012 r. liczba ta zmniejszyła się do 134. Jest to tendencja odwrotna do tej, którą można obserwować w globalnej gospodarce, gdzie procesy globalizacji spowodowały zwiększenie liczby miast, w których znajdują się siedziby zarządów najważniejszych firm na świecie (Raźniak, Winiarczyk-Raźniak 2015).

Wykres 1. Liczba siedzib zarządów największych korporacji w Europie Środkowo-Wschodniej i ich dynamika w latach 2008-2012

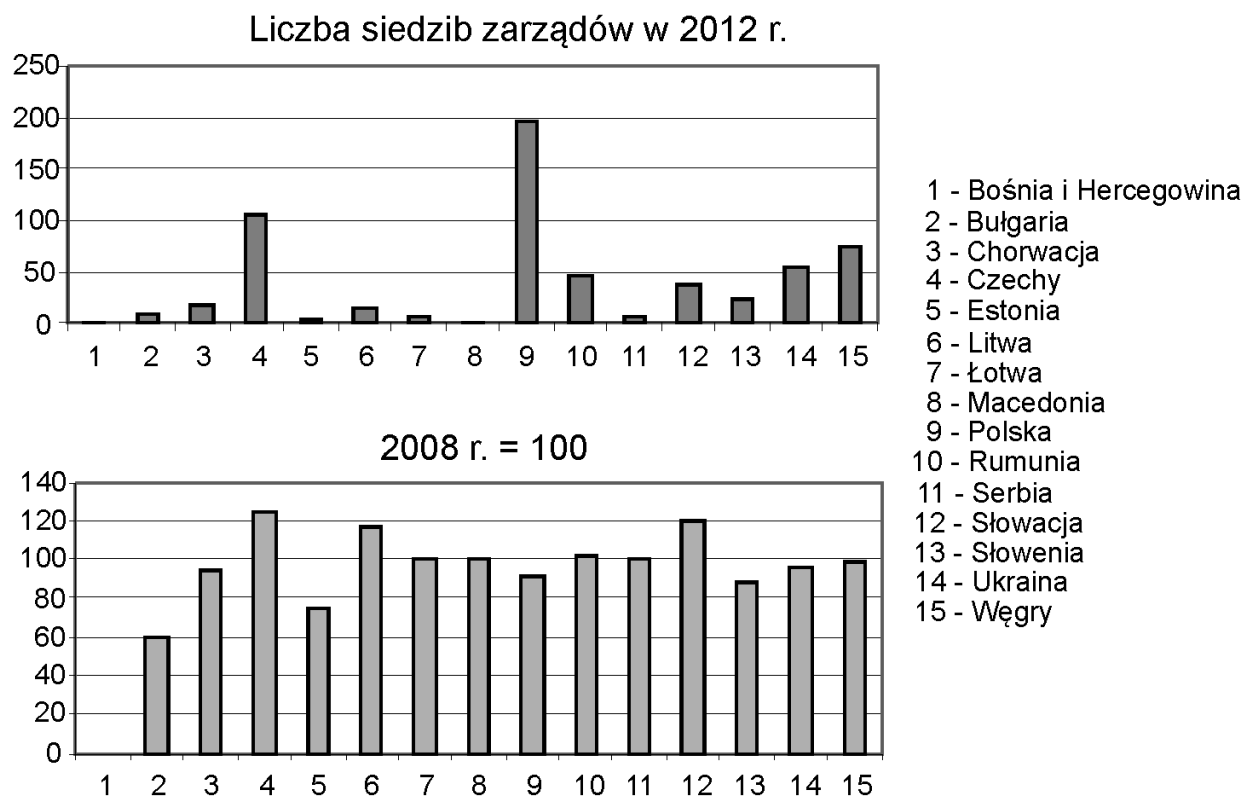

Źródło: opracowanie własne na podstawie Deloitte Central Europe Top 500 Report.

Najwięcej siedzib zarządów w 2012 r. znajdowało się w Polsce (198) i w Czechach (105) (zob. wykres 1). Należy zauważyć, że wysoka pozycja Czech podyktowana jest dominacją Pragi, gdzie znajduje się aż 73,3\% wszystkich korporacji. 
W Polsce dominacja Warszawy nie jest tak wyraźna (51\% polskich korporacji). Dosyć duża liczba korporacji występuje także na Węgrzech (75), Ukrainie (54) i w Rumunii (45). Najbardziej zwiększają swoje znaczenie korporacje czeskie, których liczba w latach 2008-2012 wzrosła aż o 23,53\%, podczas gdy w dominującej w regionie Polsce zaobserwowano ich zmniejszenie o 8,76\%. Ponadto wzrasta znaczenie korporacji słowackich $(+19,35)$, litewskich $(+16,67)$ i rumuńskich $(+2,27)$. Przychody przedsiębiorstw bułgarskich i litewskich nie nadążają za pozostałymi korporacjami w regionie, co przełożyło się na spadek ich liczby aż o $40 \%$ w Bułgarii i o $25 \%$ na Litwie. Warto również zauważyć wzrost znaczenia Bośni i Hercegowiny, w której jeszcze w 2008 r. nie było żadnej korporacji na badanej liście, a w 2012 r. znalazły się już dwie.

Wykres 2. Przychody ze sprzedaży największych korporacji Europy Środkowo-Wschodniej i ich dynamika w latach 2008-2012
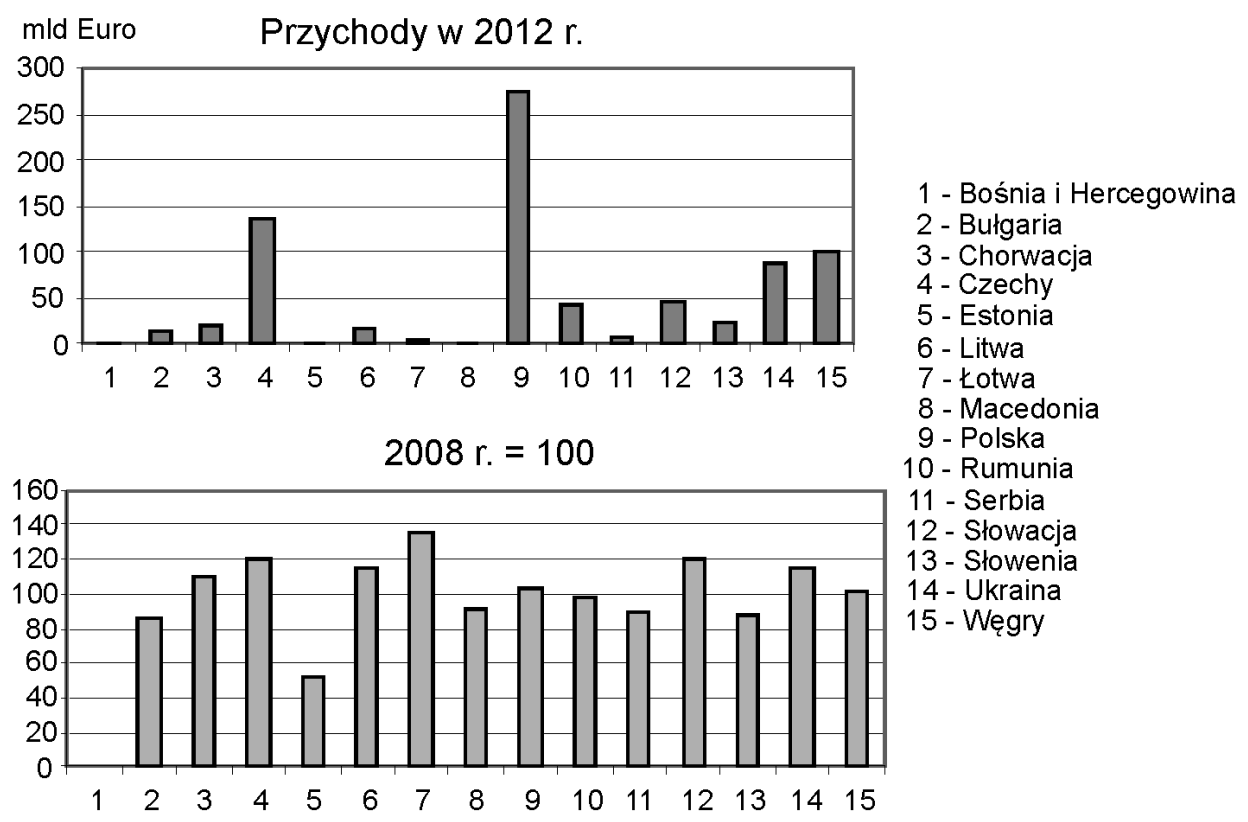

8 - Macedonia

9 - Polska 10 - Rumunia 11 - Serbia 12 - Stowacja 13 - Słowenia 14 - Ukraina 15 - Węgry

Źródło: opracowanie własne na podstawie Deloitte Central Europe Top 500 Report.

Najwyższe przychody ze sprzedaży, które w sumie wyniosły prawie 273,9 mld euro, zanotowano w Polsce; wynika to przed wszystkim z dużej liczby siedzib zarządów (zob. wykres 2). Mimo zmniejszenia się liczby korporacji w latach 20082012 w Polsce zanotowały one wzrost przychodów ze sprzedaży o 3,77\%. Ich dynamika nie była jednak tak duża, jak w przypadku Czech (19,56\%), Słowacji (20,77\%), a zwłaszcza Łotwy (35,03\%). Warto zwrócić uwagę na Łotwę, w której korporacje osiągają dosyć niskie przychody (5851 mln Euro) zwłaszcza w porów- 
naniu z Bułgarią (15 046 mln Euro). W Bułgarii mieści się tylko jedna siedziba zarządu więcej, a mimo to zanotowała ona ponad 2,5-krotnie wyższe przychody ze sprzedaży. Jeżeli jednak obecna tendencja, odnosząca się do liczby siedzib zarządów i przychodów ze sprzedaży, się utrzyma, to w ciągu kilku, kilkunastu lat Łotwa może wyprzedzić Bułgarię pod względem liczby siedzib zarządów i wyników finansowych firm.

Największe różnice zauważono w przypadku zmian dochodów netto (zob. wykres 3). Najbardziej pozytywne zmiany zaobserwowano na Litwie (382 mln euro), gdzie zwiększyły się one aż o 502,2\%. Należy jednak zauważyć, że był to wzrost z bardzo niskiej wartości (w 2008 r.). Pozytywne zmiany zaszły również w Czechach (57,05\%), na Słowacji (18,56\%) i w Polsce (13,04\%). Należy zwrócić uwagę na to, że przedsiębiorstwa czeskie wykazały prawie takie same dochody netto (11 $226 \mathrm{mln}$ euro) jak polskie (11 $280 \mathrm{mln}$ euro), mimo że ich liczna była znacznie mniejsza. W pozostałych 11 krajach omawiany wskaźnik spadł, na co mogła wpłynąć niestabilna sytuacja ekonomiczna związana ze spowolnieniem gospodarczym. Najgorsza sytuacja pod względem dochodów występuje w firmach słoweńskich, gdzie spadły one ponad 11-krotnie (-91,19\%); mogą mieć na to wpływ ogólne trudności gospodarcze przejawiające się m.in. spadkiem PKB kraju (Brozzi, Lapuh, Nared, Streifeneder 2015).

Wykres 3. Dochody netto największych korporacji Europy Środkowo-Wschodniej i ich dynamika w latach 2008-2012
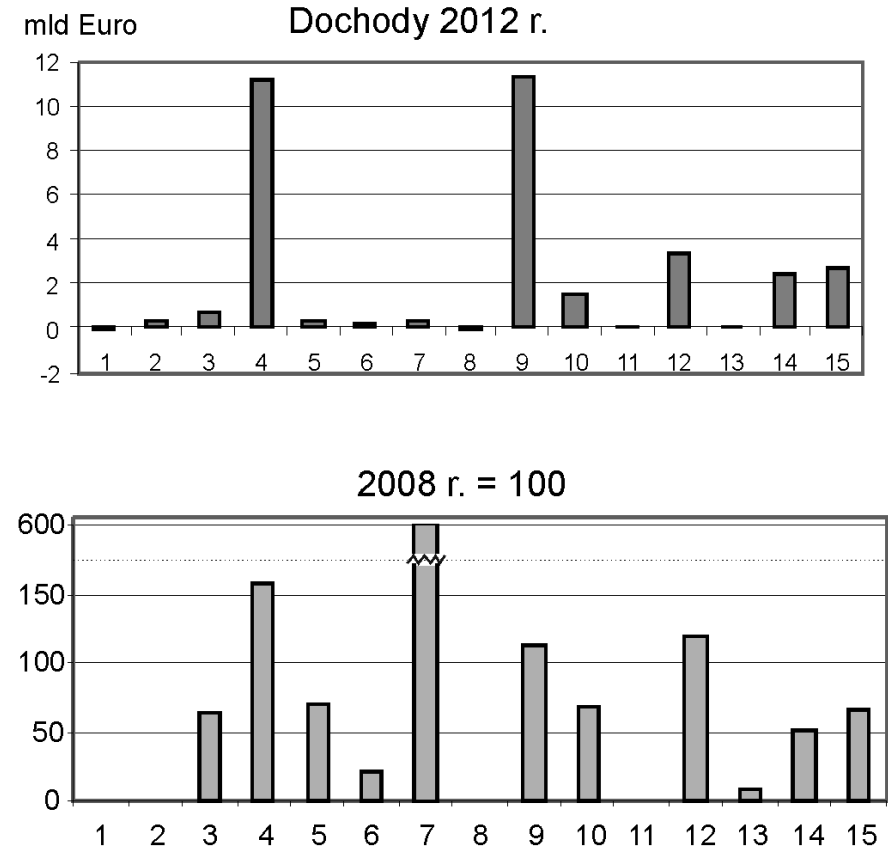

1 - Bośnia i Hercegowina

2 - Bułgaria

3 - Chorwacja

4 - Czechy

5 - Estonia

6 - Litwa

7 - Łotwa

8 - Macedonia

9 - Polska

10 - Rumunia

11 - Serbia

12 - Słowacja

13 - Słowenia

14 - Ukraina

15 - Węgry

Źródło: opracowanie własne na podstawie Deloitte Central Europe Top 500 Report. 
Liczba siedzib zarządów oczywiście nie determinuje wysokich wyników finansowych, czego przykładem mogą być Słowacja i Rumunia. Mimo że w Rumunii zlokalizowanych jest więcej korporacji, to notują one słabsze wyniki niż mniej liczne korporacje z siedzibą na Słowacji. Ponadto wydaje się, że słowackie przedsiębiorstwa są w lepszej sytuacji ekonomicznej, o czym świadczy bardzo wysoki wzrost liczby siedzib zarządów oraz przychodów ze sprzedaży i dochodów netto, podczas gdy zmniejsza się liczba przedsiębiorstw rumuńskich, a wraz z tym pogorszają się ich wyniki finansowe.

Analizowane kraje podzielono na trzy grupy ze względu na ich sytuację polityczną w regionie Europy Środkowo-Wschodniej po 1945 r. Do pierwszej grupy należą kraje, które przed 1990 r. były osobnymi organizmami państwowymi: Polska, Węgry, Bułgaria, Rumunia oraz Czechy i Słowacja. Dwa ostatnie kraje uzyskały niepodległość dopiero w 1993 r., jednak ich wydzielenie z Czechosłowacji było całkowicie pokojowe. Drugą grupę stanowią kraje, które przed rozpadem Związku Radzieckiego wchodziły w jego skład jako republiki radzieckie: Litwa, Łotwa, Estonia, Ukraina. Z kolei trzecia grupa to państwa powstałe po rozpadzie Jugosławii - w większości przypadków ich powstanie było związane z konfliktami zbrojnymi - Słowenia, Chorwacja, Bośnia i Hercegowina, Czarnogóra, Serbia, Macedonia, Kosowo. Najlepsze wyniki zanotowały państwa zaliczone do grupy 1, w których nieznacznie zwiększyła się liczba siedzib zarządów, ale znacznie szybciej rosły przychody $(+6,58 \%)$, zwłaszcza dochody $(+15,38 \%)$. W drugiej grupie krajów zauważono nieznaczny spadek liczby siedzib zarządów oraz spadek dochodów na poziomie $-45,8 \%$. Najgorsza sytuacja jest $w$ krajach, które powstały po rozpadzie Jugosławii (grupa 3) - spadek odnotowano w przypadku wszystkich trzech parametrów. Mimo że był on nieznaczny w przypadku liczby siedzib zarządów i przychodów ze sprzedaży, to zmniejszenie się dochodów netto o ponad połowę $(-55,79 \%)$ może niekorzystnie wpłynąć na kondycję finansową korporacji tego regionu.

Reasumując, można stwierdzić, że spowolnienie gospodarcze, które rozpoczęło się w 2008 r., nie wpłynęło negatywnie na kondycję finansową największych korporacji w Europie Środkowo-Wschodniej. Zanotowano prawie 7-procentowy wzrost przychodów ze sprzedaży. Co ważne, dochody netto w 2012 r. również nieznacznie wzrosły ( $+0,79 \%)$ w stosunku do roku 2008. Należy jednak pamiętać, że na poziomie państw występują bardzo duże różnice pod względem badanych wskaźników.

\section{Funkcje kontrolno-zarządcze w miastach Europy Środkowo-Wschodniej}

Analizując wskaźnik K-Z, można zaobserwować, że zarówno pod względem liczby siedzib zarządów, jak i wartości wskaźnika funkcji kontrolno-zarządczej w latach 2008 i 2012 największy potencjał, a zarazem główne funkcje kontrolno- 
-zarządcze prezentują stolice największych państw regionu: Warszawa, Praga, Budapeszt oraz Kijów, Bukareszt i Bratysława, jednakże ich znaczenie się zmniejsza (zob. rysunek 2).

Rysunek 2. Wartość wskaźnika funkcji kontrolno-zarządczych dla miast Europy Środkowo-Wschodniej w latach 2008 i 2012

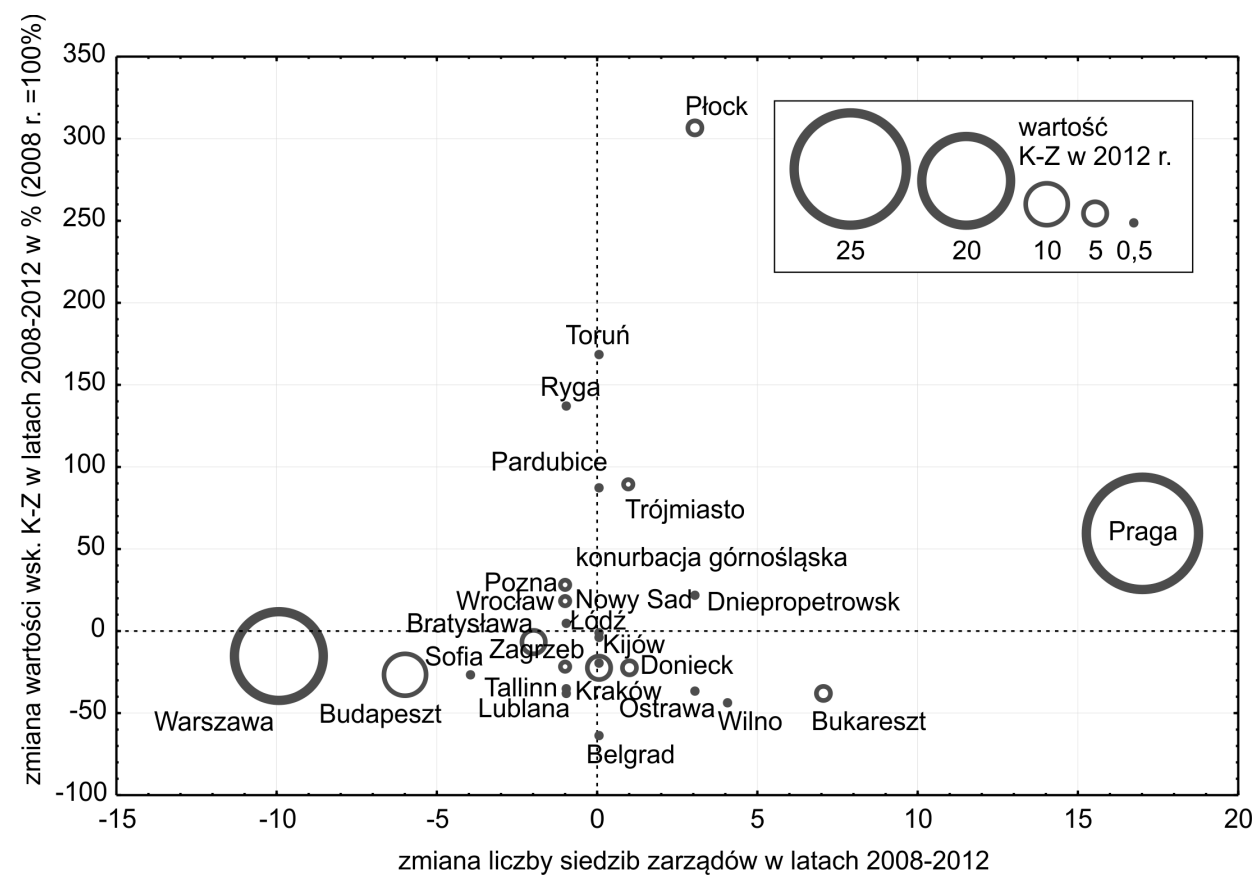

Źródło: opracowanie własne na podstawie Deloitte Central Europe Top 500 Report.

W badanym okresie spośród wymienionych stolic jedynie Praga odnotowała znaczący wzrost wartości wskaźnika K-Z (59,3\% w stosunku do 2008 r.) oraz liczby siedzib zarządów. W pozostałych przypadkach nastąpił spadek wartości wskaźnika: Bratysława $(-5,4 \%)$, Warszawa $(-14,2 \%)$, Kijów $(-21,4 \%)$ i Budapeszt $(-26,2 \%)$. Oprócz Pragi tylko dziewięć miast odnotowało wzrost, podczas gdy 16 - spadek. Największy wzrost wskaźnika K-Z odnotowały głównie miasta Polski: Płock (308\%), Toruń (169,8\%), Trójmiasto (89,3\%), konurbacja górnośląska $(28,3 \%)$, Poznań $(18,4 \%)$ i Wrocław $(6,2 \%)$. Specyficznym przykładem specjalizacji miasta jest Płock, gdzie dominuje pierwszy w zestawieniu Deloitte koncern petrochemiczny PKN Orlen (przychody na poziomie 28,7 mld euro w 2012 r.) i inne spółki z nim powiązane. Taka specjalizacja miasta w przypadku spadku cen ropy w latach 2014, 2015, 2016 może doprowadzić do zmniejszenia zysków i może zachwiać funkcjami kontrolno-zarządczymi miasta. Wysoki wzrost odnotowały również Ryga (169,8\%) oraz Pardubice (88\%). Największy 
spadek odnotowały Belgrad (-63,3\%) i Wilno (-42,8\%). Spadek powyżej 20\% zauważono również w Doniecku, Zagrzebiu, Sofii, Tallinie, Ostrawie i Lubljanie. W przypadku Bukaresztu, Wilna i Ostrawy spadek wskaźnika nastąpił nawet pomimo zwiększenia się liczby siedzib zarządów. W przypadku Rygi, konurbacji katowickiej, Poznania i Wrocławia wzrost nastąpił nawet pomimo utraty jednej siedziby zarządu w badanym czasie.

Rysunek 3. Wartość wskaźnika sektorowej funkcji kontrolno-zarządczej dla miast Europy Środkowo-Wschodniej (sK-Z) w 2012 r.

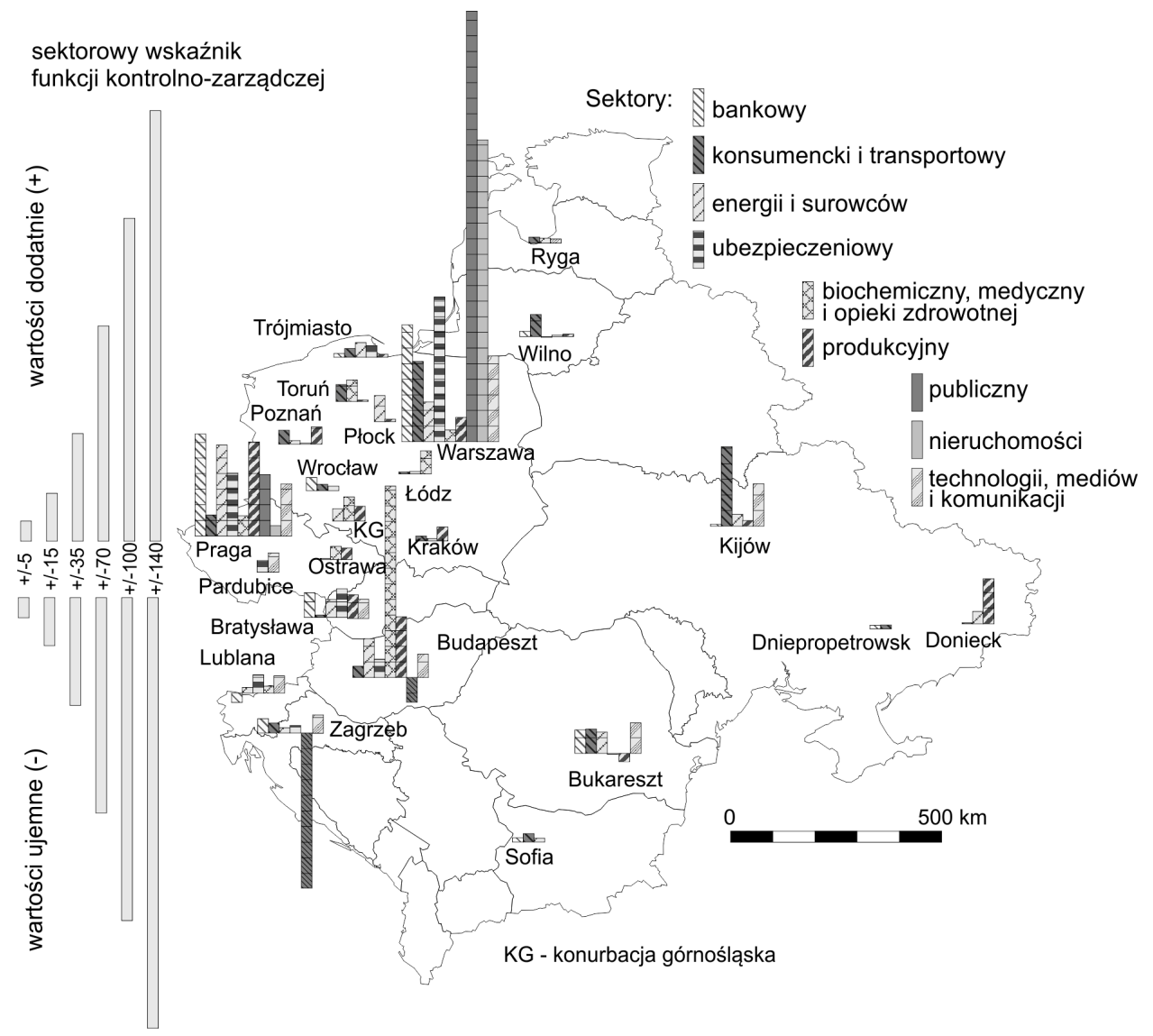

Źródło: opracowanie własne na podstawie Deloitte Central Europe Top 500 Report.

Analizując strukturę sektorową poszczególnych miast przy użyciu wskaźnika sektorowego potencjału funkcji kontrolno-zarządczej dla miast Europy Środkowo-Wschodniej (sK-Z) w 2012 r. (zob. rysunek 2), można zauważyć wyraźną dominację Warszawy - wskaźnik 395,7. Następna w kolejności była Praga z wynikiem 165,1 . Są to jedyne miasta, w których mieszczą się siedziby korporacji reprezen- 
tujące wszystkie dziewięć sektorów. Kolejnym miastem pod względem analizowanego wskaźnika jest stolica Węgier z wynikiem 102,2 pkt., z siedzibami firm reprezentujących 7 sektorów. W przypadku pozostałych miast wartość wskaźnika nie przekracza 50 pkt., a zlokalizowane w nich siedziby przedsiębiorstw reprezentują mniej niż 7 sektorów (jedynym wyjątkiem jest Lubljana, gdzie odnotowano siedem sektorów, jednak uzyskała ona wynik jedynie na poziomie 12,2). Wyróżniającymi się miastami są Kijów $(45,1)$, Bratysława $(37,2)$ oraz Bukareszt $(28,8)$. Najniższą wartość wskaźnika uzyskały Zagrzeb, Dniepropietrowsk, Ryga i Sofia.

Analizując strukturę sektorową w miastach, należy stwierdzić, że jest ona bardzo zróżnicowana. Jedynie dwa sektory są obecne we wszystkich 19 miastach: konsumencki i transportowy oraz energii i surowców. Następnymi w kolejności są produkcyjny (18 miast), ubezpieczeniowy (13) i bankowy (12). Do sektorów zlokalizowanych tylko w największych centrach należą sektor rynku nieruchomości i sektor publiczny.

Rozpatrując rozwój sektorów, można zauważyć, że w przypadku dużych miast, takich jak Warszawa czy Praga, poszczególne sektory mają podobne znaczenie, jeśli chodzi o wpływ na potencjał ekonomiczny miasta. Praga, Bratysława i Warszawa mają najniższą wartość współczynnika zmienności wartości wskaźnika sK-Z po odjęciu jednego z sektorów. Również w takich polskich ośrodkach jak konurbacja katowicka, Łódź i Poznań są równomiernie rozwinięte sektory. Z kolei w Zagrzebiu, Płocku, Bukareszcie, Wrocławiu i Wilnie jest bardzo duża specjalizacja sektorowa. Sektor bankowy decyduje o znaczeniu Pragi i Lubljany. Sektor publiczny ma duże znaczenie w Warszawie, Budapeszcie i Zagrzebiu, ubezpieczeniowy w Bratysławie i Bukareszcie. Najczęściej dominowały sektory: konsumencki i transportowy (Ryga, Dniepropietrowsk, Sofia, Kijów), medyczny i opieki zdrowotnej (Łódź, konurbacja katowicka, Ostrawa, Toruń), produkcyjny (Poznań, Kraków, Donieck, Wrocław).

Podsumowując, należy zauważyć, że w ujęciu sektorowym dominuje Warszawa - w porównaniu z 2008 r. nastąpił wzrost wskaźnika sK-Z o 30,3\% w stosunku do roku bazowego, podczas gdy w Pradze wzrost wyniósł tylko 20,4\%. Natomiast w Budapeszcie nastąpił spadek o 32,5\%. Stolica Węgier, mimo rozwoju ekonomicznego na początku XXI w., traci swoją pozycję, zwłaszcza w sektorze finansowym, na korzyść Warszawy i Pragi (Gál 2015). Wysoka pozycja Warszawy związana jest z dużą liczbą siedzib zarządów reprezentujących wszystkie sektory, zarówno w 2008, jak i w 2012 r., podczas gdy Praga osiągnęła komplet sektorów dopiero w 2012 r., a Budapeszt stracił reprezentantów aż trzech sektorów. Wysoka pozycja Warszawy związana jest głównie z sektorem publicznym i nieruchomości, nastąpił jednak drastyczny spadek w sektorze medyczny i opieki zdrowotnej. W przypadku Pragi duży wzrost miał miejsce w sektorze produkcyjnym i bankowym, a wyraźny spadek - w sektorze nieruchomości. Analizowana struktura sektorowa i jej zmiany sugerują, że rozwój korporacji był odmienny w poszczególnych miastach oraz że następuje specjalizacja poszczególnych ośrodków. 
Do lat 90. XX w. w krajach Europy Środkowo-Wschodniej w strukturze gospodarki duże znaczenie miał przemysły wydobywczy i ciężki, m.in. energetyczny, hutniczy i chemiczny (Boguś, Rachwał 2012). Obecnie w wyniku transformacji gospodarek tych krajów rośnie udział bardziej nowoczesnych działów produkcji w strukturze przemysłu (Zuzańska-Żyśko 2016). W konsekwencji struktura zatrudnienia i produkcji sprzedanej przemysłu wg działów w krajach Europy Środkowo-Wschodniej upodobniła się do tej, która występuje w wysokorozwiniętych krajach Europy Zachodniej (Rachwał 2011). Przekłada się to znaczne zróżnicowanie sektorowe w największych miastach, dzięki czemu ewentualny kryzys ekonomiczny w jednej z branż może być mniej dotkliwy.

\section{Podsumowanie}

Badania nad funkcjami kontrolno-zarządczymi miasta/obszaru metropolitalnego odnoszące się do siedzib zarządów najważniejszych korporacji są coraz bardziej popularne w literaturze światowej. W badanych firmach ogółem w latach 2008-2012 nastąpił nieznaczny wzrost zarówno przychodów, jak i dochodów, co oznacza, że spowolnienie gospodarcze nie odbiło się negatywnie na ich wynikach finansowych. Najwięcej siedzib zarządów zlokalizowanych jest w Polsce i Czechach. W Czechach zaobserwowano znaczny wzrost ich liczby, podczas gdy w Polsce zauważono odwrotną tendencję. Warto dodać, że większość firm ulokowała swoje siedziby w zachodniej części badanego regionu. Obecnie główne funkcje kontrolno-zarządcze w Europie Środkowo-Wschodniej pełnią Praga i Warszawa. Spowolnienie gospodarcze silniej wpłynęło na wyniki korporacji zlokalizowanych w stolicy Polski, ponieważ w 2008 r. to w Warszawie funkcje kontrolno-zarządcze były najbardziej rozwinięte. Ponadto w przypadku większości ośrodków stołecznych zaobserwowano spadek omawianej funkcji; wzrost zauważono przede wszystkim w miastach regionalnych. Można także stwierdzić, że zmiana liczby siedzib zarządów nie przekłada się na analogiczną zmianę omawianej funkcji. Mimo zwiększenia się liczby korporacji w Bukareszcie, Wilnie i Ostrawie ich funkcje kontrolno-zarządcze się zmniejszyły, natomiast w Rydze, konurbacji katowickiej, Poznaniu i Wrocławiu zaobserwowano odwrotną sytuację. Odnosząc się do rankingu miast według potencjału sektorowego, należy stwierdzić, że dominującym ośrodkiem pozostaje Warszawa. Następne w kolejności są Praga i Budapeszt, które charakteryzują się o wiele mniej zrównoważonym rozwojem sektorowym.

Ze względu na przeszłość historyczno-polityczną rozwój funkcji kontrolno-zarządczych miast w Europie Środkowo-Wschodniej przebiega nieco inaczej niż na świecie - w skali światowej mamy do czynienia z dekoncentracją przestrzenną lokalizacji siedzib najważniejszych korporacji, tymczasem w analizowanym regionie zaobserwowano ich koncentrację w mniejszej liczbie miast. Pozytywnym 
aspektem jest to, że w badanych korporacjach Europy Środkowo-Wschodniej w latach 2008-2012 nastąpił nieznaczny wzrost zarówno przychodów ze sprzedaży, jak i zysków netto. Jest to tendencja zgodna ze światowymi trendami w gospodarce, gdzie największe korporacje światowe zwiększają swoje przychody ze sprzedaży i zyski netto (Taylor, Csomós 2012).

\section{Bibliografia}

Alderson A.S., Beckfield, J. (2004), Power and position in the world city system, „American Journal of Sociology” 109(4), 811-51.

Brozzi R. Lapuh L., Nared J., Streifeneder T. (2015), Towards more resilient economies in Alpine regions, „Acta geographica Slovenica”, 55(2), 339-350, DOI: http://dx.doi.org/10.3986/AGS.916.

Connoly R. (2013), The Economic of Social Order Development in Post-Socialist in Eastern Europe, Routledge.

Csomós G. (2013), The Command and Control Centers of the United States (2006/2012): An Analysis of Industry Sectors Influencing the Position of Cities, „Geoforum”, 12(50), 241-251.

Csomós G. (2012), GaWC Data Set 26: Global Command and Control Centres, 2006/2009/2012, www.lboro.ac.uk.

Csomós G., Derudder B. (2014), European Cities as Command and Control Centres, 2006-11, „European Urban and Regional Studies”, 21, 345-352, DOI: $10.1177 / 0969776412453149$.

Deloitte Central Europe Top 500 Report, www.deloitte.com.

Dorocki S. (2010), Wspótczesne procesy internacjonalizacji produkcji i delokalizacji przemystu samochodowego Francji, „Prace Komisji Geografii Przemysłu Polskiego Towarzystwa Geograficznego", 16, 125-136.

Dorocki S. (2012), Regional Differentiation in the Development of French Towns - Quantitative Analysis, „Barometr Regionalny. Analizy i prognozy", 3(29), 13-31.

Dorocki S. (2014), Contemporary Trends in the Development of the Pharmaceutical Industry in the World, „Prace Komisji Geografii Przemysłu Polskiego Towarzystwa Geograficznego", 25, 108-131.

Dorocki S., Boguś M. (2014), Regional Variety of Biotechnology Development in Asia, ,Procedia - Social and Behavioral Sciences” 120:197-212, DOI: http:// dx.doi.org/10.1016/j.sbspro.2014.02.097.

Globalization and World Cities, www.lboro.ac.uk.

Friedmann J. (1986), The world city hypothesis, „Development and Change”, 17, 69-83.

Froot K.A. (1994), Foreign Direct Investment in Eastern Europe: Some Economic Considerations [w:] Blanchard O., Froot K., Sachs J. (red.), Transition in Eastern Europe, Vol. 2, 293-318, Chicago, University of Chicago Press. 
Gál Z. (2015), Development of international financial centres in Central and Eastern Europe during transition period and crisis. The case of Budapest, „Studia Regionalne i Lokalne", 60(2), 53-80, DOI: 10.7366/1509499526003.

Hall P. (1966), The World Cities, London: Heinemann, DOI: 10.1080/00420989120080651.

IMAP. Global Pharma \& Biotech Report 2014.

Kincses Á., Nagy Z., Tóth G. (2014), Modelling the spatial structure of Europe, „Regional Statistics”, 4(2): 40-54, DOI: 10.15196/RS04203.

Liu X., Derudder B., Witlox F., Hoyler M. (2014), Cities As Networks within Networks of Cities: The Evolution of the City/Firm-Duality in the World City Network, 2000-2010, „Tijdschrift voor economische en sociale geographie”, 105(4): 465-482, DOI: 10.1111/tesg.12097.

Lyons D., Salmon S. (1995), World cities, multinational corporations, and urban hierarchy: the case of the United States [w:] Knox P.L., Taylor P.J. (red.), World cities in a World-system, Cambridge University Press, Cambridge, 98-114.

Rachwał T. (2011), Industrial restructuring in Poland and other European Union states in the era of economic globalization, „Procedia. Social and Behavioral Sciences", Vol. 19 (2011), 1-10, DOI:10.1016/j.sbspro.2011.05.100.

Rachwał T., Boguś M. (2012), The Competitiveness of Industrial Enterprises in European Union Countries [w:] Krstić B., Chodyński A. (red.), Current problems of Competitiveness Improvement in National Economies and Enterprises, Faculty of Economics, University of Niš, Serbia, Niš, 133-156, DOI: 10.2478/v10117-012-0021-9.

Raźniak P., Dorocki D., Winiarczyk-Raźniak A. (2017), Permanence of the economic potential of cities based on sector development, „Chinese Geographical Science" 1(27).

Raźniak, P., Dorocki, S., Winiarczyk-Raźniak, A. (2015), Ranga miasta w świetle syntetycznego wskaźnika stabilności gospodarczej, „Studia Miejskie”, 18, 119-130.

Raźniak P., Nowotnik D. (2015), Pozycja gospodarcza miast Europy Środkowo-Wschodniej na tle świata, „Ekonomia Międzynarodowa”, 9, 23-39.

Raźniak P., Winiarczyk-Raźniak A. (2015), Did the 2008 global economic crisis affect large firms in Europe? „Acta Geographica Slovenica”, 55(1), 127-139, DOI: http://dx.doi.org/10.3986/AGS.740.

Raźniak P., Winiarczyk-Raźniak A., Nowotnik D. (2015), Central and Eastern European Cities in globalized world, „Socio-Economic Problems and the State", 12(1), 22-33, UDC 339.922:330.

Raźniak P., Winiarczyk-Raźniak A. (2014), Sytuacja finansowa korporacji europejskich $w$ dobie kryzysu, „Prace Komisji Geografii Przemysłu Polskiego Towarzystwa Geograficznego", 27, 99-117.

Rosińska-Bukowska M. (2015), Internacjonalizacja przedsiębiorstw - istota budowania konkurencyjności $w$ dobie globalizacji korporacyjnej, „Ekonomia Międzynarodowa", 8, 153-171. 
Sassen S. (1991), The Global City: New York, London, Tokyo, Princeton, Princeton University Press.

Sassen S. (2000), The Global City: Strategic Site/New Frontier, „American Studies", 41 (2/3), 79-95.

Sassen S. (2006), Cities in a world economy, 3rd Edition, Pine Forge Press, Thousand Oaks.

Sassen S. (2011), Cities in a world economy, 4th edition, Sage Publications.

Smętkowski M. (2015), The impact of the economic crisis on the metropolisation process in the capital cities of the CEE countries, „Studia Regionalne i Lokalne", 2(60), 32-52, DOI: 10.7366/1509499526002.

Smętkowski M. (2014), Źródła wzrostu gospodarczego w regionach krajów Europy Środkowo-Wschodniej-dezagregacja strukturalna, ,Studia Regionalne i Lokalne", 56(2), 5-27, DOI: 10.7366/1509499525601.

Taylor P.J. (2004), World City Network: A Global Urban Analysis, London.

Taylor P.J., Csomós G. (2012), Cities as control and command centres: Analysis and interpretation, „Cities”, 29(6), 408-411.

Tsenkova S. (2008), Managing change: the comeback of post-socialist cities, „Urban Research \& Practice", Vol. 1, No. 3, 291-310.

Wojciechowski L., Lubacha-Sember J. (2014), Uwarunkowania przepływu polskich bezpośrednich inwestycji zagranicznych do krajów Unii Europejskiej. Model grawitacyjny z wykorzystaniem danych panelowych, „Ekonomia Międzynarodowa", 7, 136-149.

Wójtowicz M., Dorocki S. (2014), Regional differences in the development of the biotechnology industry in Latin America, with particular emphasis on Brazil and Mexico [w:] Wójtowicz M., Winiarczyk-Raźniak A. (red.) Environmental and socio-economic transformations in developing areas as the effect of globalization, Kraków, Wydawnictwo Naukowe UP, 111-135.

Tsenkova S. (2008), Managing change: the comeback of post-socialist cities, „Urban Research \& Practice", Vol. 1, No. 3, 291-310.

Zuzańska-Żyśko E. (2016), Procesy metropolizacji. Teoria i praktyka, PWN, Warszawa.

Globalization and World Cities, www.lboro.ac.uk.

\section{Streszczenie}

Wielkie korporacje mają duży wpływ na rangę miasta na arenie międzynarodowej. Celem artykułu jest określenie poziomu rozwoju funkcji kontrolno-zarządczych miast Europy Środkowo-Wschodniej. Określono je na podstawie przychodów ze sprzedaży i zysku netto 600 korporacji (dla lat 2008 i 2012), których siedziby zarządów zlokalizowane są w Europie Środkowo-Wschodniej, oraz wpływu poszczególnych sektorów na tę funkcję. Na podstawie przeprowadzonych badań wykazano, że mimo spowolnienia gospodarczego w latach 2008-2012 przychody 
i dochody badanych korporacji nieznacznie się zwiększyły. Najwyższy rozwój funkcji kontrolno-zarządczych $\mathrm{w}$ analizowanym regionie odnotowano $\mathrm{w}$ dwóch stolicach: Pradze i Warszawie. Ponadto zauważono zmniejszenie się liczby miast, w których zlokalizowane były siedziby zarządów, co jest odmienną tendencją od obserwowanej w skali globalnej.

Słowa kluczowe: funkcje kontrolno-zarządcze, Europa Środkowo-Wschodnia, Deloitte, korporacje, siedziby zarządów

\section{Summary}

The Dynamics of Control and Managerial Functions In Central and Eastern European Cities in the Time of the Economic Slowdown

Large corporations are an important aspect influencing the status of the city in the international context. The aim of this article is to determine the level of development of the command and control functions of cities in Central and Eastern Europe. These functions are defined on the basis of revenues from sales and net income of 600 corporations whose headquarters are located in Central and Eastern Europe for the years 2008 and 2012. The impact of each sector was also examined. During the economic slowdown in 2008-2012, revenues from sales and net income of the examined corporations slightly increased. The highest level of development of control and management functions has been observed in two capitals: Prague and Warsaw. In addition, a decrease in the number of cities in which the head offices were located was noted, which is different from the trend observed on a global scale.

Keywords: command and control functions, Central Europe, Deloitte, corporation, headquarters

JEL: D22, F69, R12 